\title{
Outbreak of human leptospirosis linked to contaminated water bodies in Northern Israel, June to August 2018
}

Yuval Dadon ${ }^{1,2,3}$, Eric J. Haas ${ }^{2,3,4}$, Ehud Kaliner5, Emilia Anis ${ }^{2,6}$, Shepherd Roee Singer ${ }^{2,6}$, Yafit Atiya-Nasagi ${ }^{7}$, Michal Cohen-Dar,

Eva Avramovich', Roni King ${ }^{10}$, Oded Sued ${ }^{11}$, Tamir Goshen ${ }^{12}$, Sharon Amit ${ }^{13}$, Ian Miskin ${ }^{14}$, Efrat Gino ${ }^{15}$, Ruth Yishai ${ }^{5}$, Rivka Sheffer ${ }^{5}$, Itamar Grotto ${ }^{1,4}$, Jacob Moran-Gilad $1,4,5$

1. Ministry of Health Directorate, Jerusalem, Israel

2. The Division of Epidemiology, Public Health Services, Ministry of Health, Jerusalem, Israel

3. These authors contributed equally to the study

4. School of Public Health, Faculty of Health Sciences, Ben-Gurion University of the Negev, Beer-Sheva, Israel

5. Public Health Services, Ministry of Health, Jerusalem, Israel

6. Braun School of Public Health and Community Medicine, Hebrew University and Hadassah, Jerusalem, Israel

7. Israel Institute for Biological Research, Ness Ziona, Israel

8. Northern District, Ministry of Health, Israel

9. Public Health Branch, IDF Medical Corps, Israel

10. Nature and Parks Authority, Jerusalem, Israel

11. Mekorot Central Laboratory, Eshkol Site, National Water Company, Israel

12. Israeli Veterinary Services, Ministry of Agriculture and Rural Development, Beit Dagan, Israel

13. Hadassah Medical Center, Jerusalem, Israel

14. Jerusalem District, Clalit Health Services, Jerusalem, Israel

15. Public Health Laboratory, Haifa District, Ministry of Health, Haifa, Israel

Correspondence: Jacob Moran-Gilad (giladko@post.bgu.ac.il)

Dadon Yuval, Haas Eric J., Kaliner Ehud, Anis Emilia, Singer Shepherd Roee, Atiya-Nasagi Yafit, Cohen-Dar Michal, Avramovich Eva, King Roni, Sued Oded, Goshen Tamir, Amit Sharon, Miskin Ian, Gino Efrat, Yishai Ruth, Sheffer Rivka, Grotto Itamar, Moran-Gilad Jacob. Outbreak of human leptospirosis linked to contaminated water bodies in Northern Israel, June to August 2018. Euro Surveill. 2018;23(38):pii=1800486. https://doi.org/10.2807/1560-7917.ES.2018.23.38.1800486

We report preliminary findings of a large outbreak of human leptospirosis with 36 confirmed/probable and 583 suspected cases from June-August 2018, linked to contaminated water bodies in Northern Israel. There was a travel-associated case in Germany; additional cases are being investigated in other countries. The presumed chain of transmission, implicating wild boar and cattle, raises multiple challenges for risk assessment, risk management and risk communication currently being addressed by a public health response team.

Leptospirosis is a common zoonotic disease worldwide, especially in tropical areas, which is associated with human exposure to pathogenic Leptospira. Here we describe an ongoing outbreak investigation and the public health response to human leptospirosis cases linked to exposure to contaminated recreational water bodies in Northern Israel.

\section{Outbreak detection}

In 9 August 2018, 15 cases, including a group of soldiers travelling together, with an acute febrile syndrome consistent with acute leptospirosis were notified from various hospitals across Israel, instigating an outbreak investigation. A potential common exposure was quickly recognised as being linked to recreational activities (including water rafting or kayaking) in several popular water bodies in Northern Israel, during the 3 weeks before onset of illness. Of note is that the implicated water bodies are heavily attended each year by the public in July and August. During recent years and especially in 2018, multi-year drought conditions resulted in seasonally low water levels in the region. Public water bodies in Israel are routinely monitored and inspected for faecal contamination according to national regulations for recreational water quality and in the past have been required to close to the public due to abnormal faecal contamination levels during the summertime.

\section{Immediate public health response}

The public health response, led by the Public Health Services of the Israeli Ministry of Health $(\mathrm{MOH})$, included the formation of a multi-disciplinary outbreak control team. This team included a range of experts and stakeholders such as infectious disease specialists, epidemiologists, microbiologists, the Veterinary Services at the Ministry of Agriculture, the Nature and Parks Authority and the National Water Authority and Water company (Mekorot) and communication specialists. An outbreak case definition formulated collaboratively by the outbreak control team can be seen in the Box. 
Case definition for leptospirosis outbreak, formulated by the outbreak control team, Israel, 14 August, 2018

Suspected cases $^{\text {a }}$ individuals with any acute febrile illness accompanied by relevant symptoms or signs (modified from United States Centers for Disease Control and Prevention [1]), occurring within 2 days to 3 weeks of recent exposure to the relevant water bodies ${ }^{b}$.

Probable cases: suspected cases with a borderline-positive serology to leptospirosis (1:50 to 1:150).

Confirmed cases: suspected cases with laboratory confirmation of leptospirosis using molecular techniques (positive realtime polymerase chain reaction (PCR) for pathogenic leptospires applied on blood or urine samples) and/or serology (positive microagglutination test (MAT), using a panel of 24 antigens, defined as a single titre of 1:200 or more or a fourfold rise of titre over 10 or more days).

${ }^{a}$ At the time of writing, convalescent-phase sera have not yet been received and tested for the vast majority of cases and since initial negative PCR and/or MAT cannot rule out leptospirosis, patients meeting the case definition but with negative serology were classified as 'suspected' and not excluded.

bThe case definition initially included four body sites (Zavitan, Yehudiya, Meshushim and Zaki). Three additional sites were added a few days later following the recognition of additional exposure sites.

\section{FIGURE 1}

Epidemic curve for human leptospirosis in Northern Israel, June-August 2018 (n = 619)

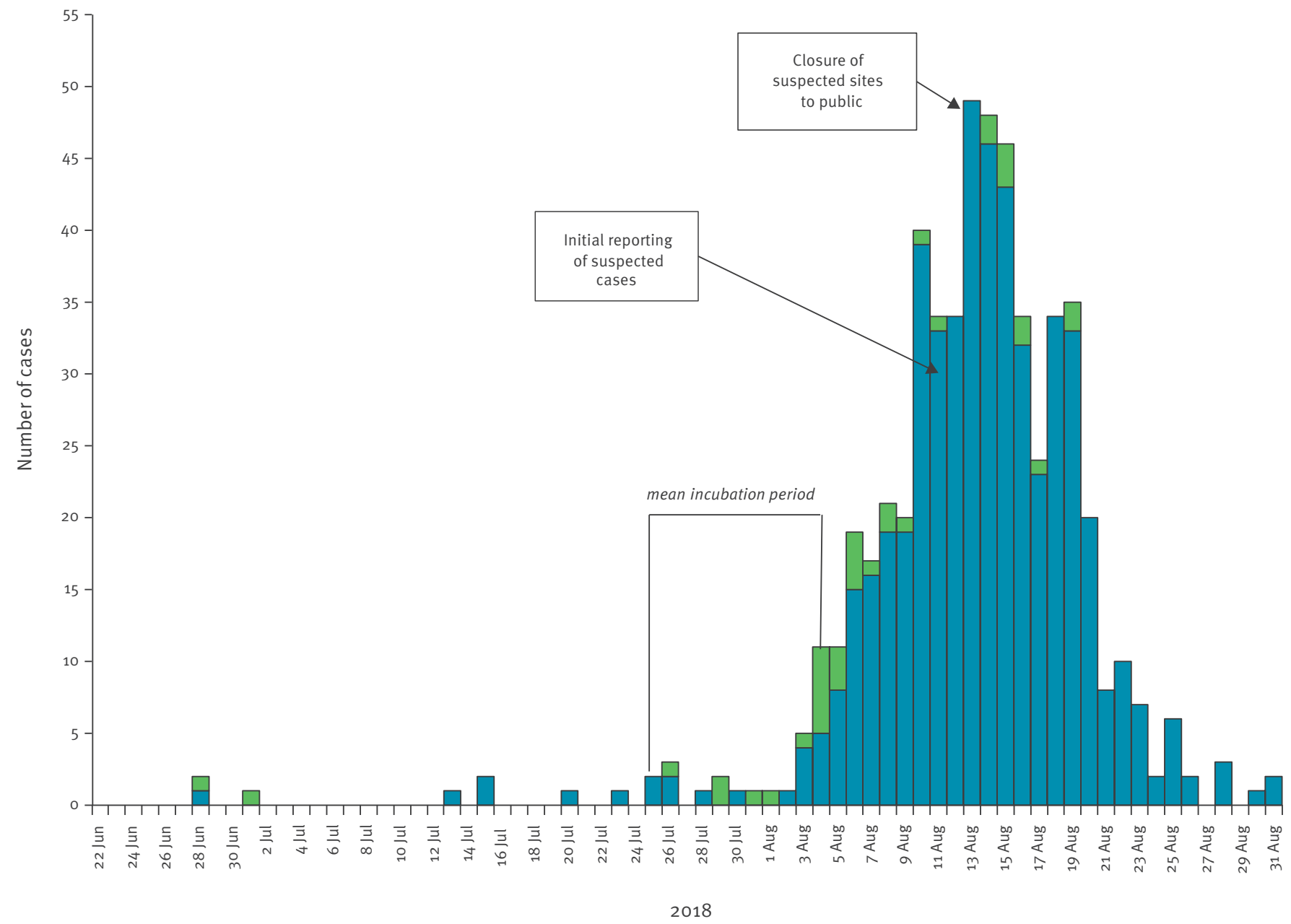

Date of onset of illness

$\square$ Clinically suspected cases $\square$ Laboratory-confirmed cases 
TABLE A

Characteristics of laboratory-confirmed and probable cases of leptospirosis, Israel, June-August $2018(\mathrm{n}=36)$

\begin{tabular}{|c|c|c|c|c|c|c|}
\hline $\begin{array}{l}\text { Date of } \\
\text { onset of } \\
\text { illness in } \\
2018\end{array}$ & $\begin{array}{l}\text { Incubation } \\
\text { period } \\
\text { (days) }\end{array}$ & $\begin{array}{l}\text { Relevant } \\
\text { exposure }\end{array}$ & Clinical symptoms & Illness severity & Laboratory results & $\begin{array}{l}\text { Case- } \\
\text { classification }\end{array}$ \\
\hline 28 June & 13 & Meshushim pool & Fever, chills, weakness, myalgia & Hospitalised & MAT $\geq 1: 200$ & Confirmed \\
\hline 1 July & 9 & $\begin{array}{l}\text { Jordan Park/ } \\
\text { Arik Bridge }\end{array}$ & $\begin{array}{l}\text { Fever, weakness, headache, } \\
\text { myalgia, vomiting }\end{array}$ & $\begin{array}{l}\text { Hospitalised, renal } \\
\text { failure }\end{array}$ & MAT $\geq 1: 200$ & Confirmed \\
\hline 26 July & 2 & Meshushim pool & $\begin{array}{l}\text { Fever, chills, weakness, headache, } \\
\text { myalgia }\end{array}$ & $\begin{array}{l}\text { Hospitalised, renal } \\
\text { failure, elevated liver } \\
\text { enzymes }\end{array}$ & MAT $=1: 100$ & Probable \\
\hline 29 July & 2 & Zavitan stream & $\begin{array}{l}\text { Fever, weakness, headache, } \\
\text { myalgia, vomiting }\end{array}$ & $\begin{array}{l}\text { Hospitalised, elevated } \\
\text { creatinine and liver } \\
\text { enzymes }\end{array}$ & MAT $\geq 1: 200$ & Confirmed \\
\hline 31 July & 2 & \begin{tabular}{|c|}
$\begin{array}{c}\text { Jordan Park/Arik } \\
\text { Bridge }\end{array}$ \\
\end{tabular} & $\begin{array}{c}\text { Fever, weakness, headache, } \\
\text { myalgia }\end{array}$ & Hospitalised & Positive PCR & Confirmed \\
\hline 1 August & 7 & Zavitan stream & $\begin{array}{l}\text { Fever, chills, weakness, headache, } \\
\text { myalgia }\end{array}$ & $\begin{array}{l}\text { Hospitalised, renal } \\
\text { failure, elevated liver } \\
\text { enzymes }\end{array}$ & MAT $\geq 1: 200$ & Confirmed \\
\hline 3 August & 10 & \begin{tabular}{|c|}
$\begin{array}{l}\text { Yehudiya forest } \\
\text { reserve }\end{array}$ \\
\end{tabular} & Fever, chills, weakness, headache & Hospitalised & MAT $\geq 1: 200$ & Confirmed \\
\hline 4 August & 12 & \begin{tabular}{|c|}
$\begin{array}{l}\text { Yehudiya forest } \\
\text { reserve }\end{array}$ \\
\end{tabular} & $\begin{array}{l}\text { Fever, weakness, headache, } \\
\text { vomiting }\end{array}$ & Hospitalised & MAT $\geq 1: 200$ & Confirmed \\
\hline 4 August & 8 & Meshushim pool & $\begin{array}{c}\text { Fever, chills, weakness, headache, } \\
\text { conjunctivitis, myalgia, cough, } \\
\text { vomiting, diarrhoea }\end{array}$ & $\begin{array}{l}\text { Hospitalised, renal } \\
\text { failure, elevated liver } \\
\text { enzymes }\end{array}$ & MAT $\geq 1: 200$ & Confirmed \\
\hline 4 August & 7 & \begin{tabular}{|c|}
$\begin{array}{l}\text { Yehudiya forest } \\
\text { reserve }\end{array}$ \\
\end{tabular} & Fever, headache, myalgia, nausea, & Hospitalised, pneumonia & MAT $\geq 1: 200$ & Confirmed \\
\hline 4 August & 6 & Meshushim pool & $\begin{array}{c}\text { Fever, chills, weakness, headache, } \\
\text { myalgia }\end{array}$ & Hospitalised & MAT $\geq 1: 200$ & Confirmed \\
\hline 4 August & 11 & Meshushim Pool & Fever, headache & $\begin{array}{c}\text { Emergency department, } \\
\text { immunocompromised at } \\
\text { baseline }\end{array}$ & $M A T \geq 1: 200$ & Confirmed \\
\hline 4 August & 10 & Meshushim Pool & $\begin{array}{c}\text { Fever, chills, weakness, headache, } \\
\text { myalgia, }\end{array}$ & Ambulatory & $M A T \geq 1: 200$ & Confirmed \\
\hline 5 August & 12 & $\begin{array}{l}\text { Yehudiya forest } \\
\text { reserve }\end{array}$ & $\begin{array}{l}\text { Fever, chills, weakness, headache, } \\
\text { myalgia }\end{array}$ & $\begin{array}{c}\text { Hospitalised, renal } \\
\text { failure and elevated liver } \\
\text { enzymes }\end{array}$ & $\begin{array}{l}\text { Positive PCR, } \\
\text { MAT } \geq 1: 200\end{array}$ & Confirmed \\
\hline 5 August & 9 & Meshushim pool & $\begin{array}{l}\text { Fever, headache, myalgia } \\
\text { vomiting, rash }\end{array}$ & Hospitalised & MAT 1:100 & Probable \\
\hline 5 August & 9 & Zaki stream & $\begin{array}{l}\text { Fever, weakness, myalgia, } \\
\text { vomiting }\end{array}$ & Hospitalised & $\begin{array}{l}\text { Positive PCR, } \\
\text { MAT } \geq 1: 200\end{array}$ & Confirmed \\
\hline 5 August & 5 & Meshushim pool & Pending investigation & Pending investigation & $\begin{array}{c}M A T \geq 1: 200 \\
\text { (seroconversion) }\end{array}$ & Confirmed \\
\hline 6 August & 19 & Zaki stream & $\begin{array}{c}\text { Fever, chills, weakness, headache, } \\
\text { myalgia }\end{array}$ & Hospitalised & MAT $\geq 1: 200$ & Confirmed \\
\hline 6 August & 14 & \begin{tabular}{|c|}
$\begin{array}{c}\text { Yehudiya forest } \\
\text { reserve }\end{array}$ \\
\end{tabular} & \begin{tabular}{|c|} 
Fever, chills, weakness, headache, \\
myalgia
\end{tabular} & Hospitalised & MAT $\geq 1: 200$ & Confirmed \\
\hline 6 August & 2 & $\begin{array}{l}\text { Yehudiya forest } \\
\text { reserve }\end{array}$ & $\begin{array}{l}\text { Fever, weakness, myalgia, } \\
\text { headache, vomiting, diarrhoea, } \\
\text { leukopenia, thrombocytopenia }\end{array}$ & $\begin{array}{l}\text { Hospitalised, intensive } \\
\text { care }\end{array}$ & Positive PCR & Confirmed \\
\hline 7 August & 10 & Meshushim pool & $\begin{array}{l}\text { Fever, headache, myalgia, } \\
\text { jaundice }\end{array}$ & Hospitalised & $\begin{array}{l}\text { MAT } \geq 1: 200 \\
\text { (seroconversion) }\end{array}$ & Confirmed \\
\hline 8 August & 4 & The Majrasa & $\begin{array}{l}\text { Fever, chills, weakness, headache, } \\
\text { myalgia }\end{array}$ & $\begin{array}{l}\text { Hospitalised, intensive } \\
\text { care }\end{array}$ & Positive PCR & Confirmed \\
\hline
\end{tabular}

MAT: microagglutination test; PCR: Polymerase chain reaction. 


\begin{tabular}{|c|c|c|c|c|c|c|}
\hline $\begin{array}{l}\text { Date of } \\
\text { onset of } \\
\text { illness in } \\
2018\end{array}$ & $\begin{array}{l}\text { Incubation } \\
\text { period } \\
\text { (days) }\end{array}$ & $\begin{array}{l}\text { Relevant } \\
\text { exposure }\end{array}$ & Clinical symptoms & Illness severity & Laboratory results & $\begin{array}{l}\text { Case- } \\
\text { classification }\end{array}$ \\
\hline 8 August & 15 & Zaki stream & $\begin{array}{l}\text { Fever, weakness, headache, } \\
\text { myalgia }\end{array}$ & $\begin{array}{c}\text { Hospitalised, renal } \\
\text { failure, elevated liver } \\
\text { enzymes }\end{array}$ & $M A T \geq 1: 200$ & Confirmed \\
\hline 9 August & 9 & Meshushim pool & $\begin{array}{l}\text { Fever, weakness, headache, } \\
\text { myalgia, arthralgia }\end{array}$ & Emergency department & Positive PCR & Confirmed \\
\hline 10 August & 12 & Meshushim pool & $\begin{array}{l}\text { Fever, weakness, headache, } \\
\text { myalgia, vomiting, diarrhoea }\end{array}$ & Hospitalised & Positive PCR & Confirmed \\
\hline 11 August & 12 & The Majrasa & $\begin{array}{l}\text { Fever, chills, weakness, headache, } \\
\text { myalgia, vomiting }\end{array}$ & $\begin{array}{l}\text { Hospitalised, intensive } \\
\text { care }\end{array}$ & MAT $=1: 50$ & Probable \\
\hline 14 August & 19 & $\begin{array}{c}\text { Yehudiya forest } \\
\text { reserve }\end{array}$ & Pending investigation & Pending investigation & MAT > 1:200 & Confirmed \\
\hline 14 August & 11 & $\begin{array}{l}\text { Jordan Park/ } \\
\text { Arik Bridge }\end{array}$ & $\begin{array}{l}\text { Fever, chills, weakness, headache, } \\
\text { myalgia }\end{array}$ & Hospitalised & Positive PCR & Confirmed \\
\hline 15 August & 21 & $\begin{array}{l}\text { Yehudiya forest } \\
\text { reserve }\end{array}$ & $\begin{array}{l}\text { Fever, chills, weakness, myalgia, } \\
\text { conjunctivitis }\end{array}$ & $\begin{array}{l}\text { Hospitalised, elevated } \\
\text { liver enzymes }\end{array}$ & Positive PCR & Confirmed \\
\hline 15 August & 10 & $\begin{array}{l}\text { Jordan Park/ } \\
\text { Arik Bridge }\end{array}$ & $\begin{array}{l}\text { Fever, chills, weakness, headache, } \\
\text { jaundice }\end{array}$ & $\begin{array}{l}\text { Hospitalised, elevated } \\
\text { liver enzymes }\end{array}$ & Positive PCR & Confirmed \\
\hline 15 August & 13 & Zavitan Stream & $\begin{array}{l}\text { Fever, chills, weakness, headache, } \\
\text { myalgia, vomiting }\end{array}$ & Hospitalised & Positive PCR & Confirmed \\
\hline 16 August & 10 & Gilabon Stream & $\begin{array}{l}\text { Fever, weakness, headache, } \\
\text { myalgia, vomiting }\end{array}$ & Hospitalised & Positive PCR & Confirmed \\
\hline 16 August & 6 & Meshushim Pool & $\begin{array}{l}\text { Fever, chills, myalgia, vomiting, } \\
\text { conjunctivitis }\end{array}$ & Hospitalised & Positive PCR & Confirmed \\
\hline 17 August & 8 & Gilabon Stream & $\begin{array}{l}\text { Fever, weakness, headache, } \\
\text { vomiting }\end{array}$ & Hospitalised & Positive PCR & Confirmed \\
\hline 19 August & 9 & $\begin{array}{l}\text { Jordan Park/ } \\
\text { Arik Bridge }\end{array}$ & $\begin{array}{l}\text { Fever, chills, weakness, headache, } \\
\text { myalgia, diarrhoea, conjunctivitis }\end{array}$ & $\begin{array}{l}\text { Hospitalised, renal } \\
\text { failure }\end{array}$ & Positive PCR & Confirmed \\
\hline 19 August & 17 & Gilabon Stream & Fever, chills, weakness, myalgia & $\begin{array}{l}\text { Hospitalised, renal } \\
\text { failure }\end{array}$ & Positive PCR & Confirmed \\
\hline
\end{tabular}

MAT: microagglutination test; PCR: Polymerase chain reaction.

Active retrospective and prospective surveillance of leptospirosis cases was initiated. The $\mathrm{MOH}$ notified the public through various media channels about the outbreak and recommended that individuals meeting the case definition seek medical advice in community clinics or hospitals. The $\mathrm{MOH}$ issued detailed guidance for healthcare professionals concerning the diagnosis, treatment alternatives and reporting of suspected leptospirosis in the community and hospital settings. Empiric age-based antimicrobial therapy was recommended for suspected cases at the discretion of attending physicians. Antimicrobial prophylaxis and personal protective equipment were recommended for potential occupational exposures (e.g. water inspectors in the region). The seven water bodies linked to suspected leptospirosis cases were closed to the public until further notice and the closure was publicised through a variety of media channels.

\section{Public health microbiology response}

Based on continuous risk assessment, the $\mathrm{MOH}$ increased the frequency of recreational water quality sampling to two to three times per week at the implicated sites (Public Health Laboratory, Haifa), as well as in a range of other water bodies in Northern Israel where human illness had not been reported. Under the assumption (and in line with the epidemiological hypothesis) that faecal coliforms could serve as a surrogate marker for animal-derived contamination of water, the microbial thresholds for site closure were lowered from 1,000 to 400 colony-forming units (cfu)/100mL of faecal coliforms. The National Reference Laboratory for Leptospirosis (Israel Institute for Biological Research (IIBR), Ness Ziona), mounted a surge response in order to process a large number of clinical samples by means of a duplex real-time polymerase chain reaction (PCR) for pathogenic leptospires (targeting the 16S rRNA and the LipL32 genes) and microagglutination test (MAT). A real-time PCR testing of water for the implicated water 


\section{FIGURE 2}

Spatial distribution of leptospirosis cases in Northern Israel, June-August $2018(\mathrm{n}=540)$

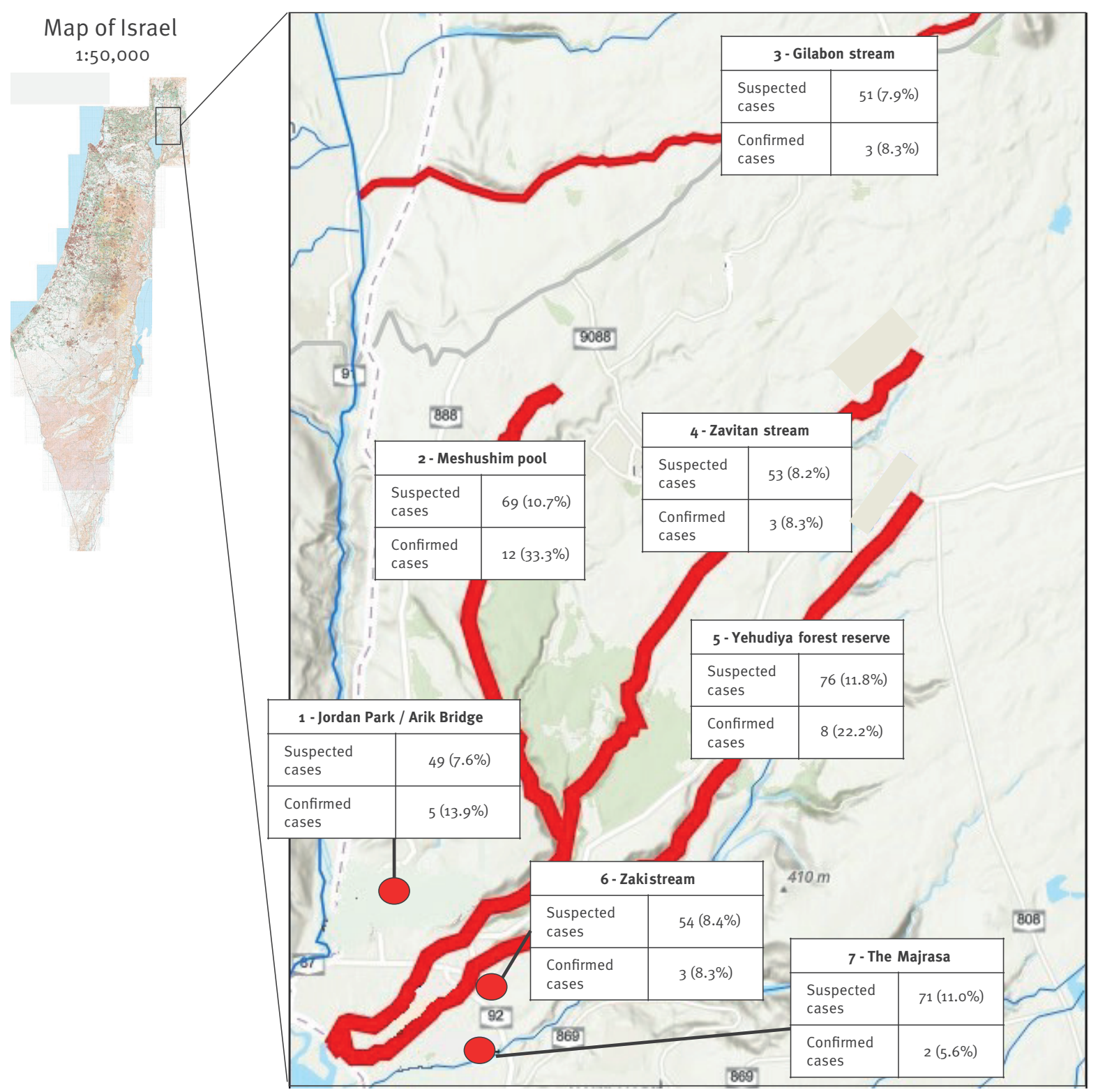

Spatial representation of seven water sources implicated in acquisition of leptospirosis in Northern Israel. All 36 confirmed/probable cases were linked to at least one of the seven sites (5.6-33.3\%). Among the remaining 504 suspected cases, there were 423 potential exposures to these seven sites (7.6-11.8\%). The figure zooms in on the region north-east to the Sea of Galilee. Red lines represent contaminated streams.

bodies has also been performed on a 'research use only' basis. In addition, a series of quantitative molecular tests using the microbial source tracking (MST) strategy for detection of faecal contamination source was deployed (Mekorot Central Laboratory) [2].

\section{Outbreak description}

As of 31 August 2018, 619 suspected cases of leptospirosis had been notified to the $\mathrm{MOH}$, of which 33 were laboratory-confirmed and three were probable. The remaining cases had initial negative MAT and/or PCR (leptospirosis not ruled out). The epidemic curve of the outbreak is shown in Figure 1.

Retrospective case finding identified a confirmed case of infection afflicting a water inspector dating back to June 2018. The characteristics of laboratory-confirmed cases are summarised in Table 1 . Of the 33 laboratoryconfirmed and three probable cases, 31 were male and the median age was 20 years (mean 25 , range $7-64$ ). The incubation period ranged from 2-21 days (mean 9.9 days, median 10 days). Influenza-like symptoms 


\section{FIGURE 3}

Faecal contamination of water bodies in Northern Israel, June-August 2018

\begin{tabular}{|l|c|c|c|c|c|c|c|}
\hline \multirow{2}{*}{ Water source } & \multicolumn{7}{|c|}{ Contamination Level (Faecal coliforms / 100mL) } \\
\hline Day count & 0 & 16 & 17 & 24 & 25 & 29 & 31 \\
\hline Date in 2018 & 22 Jul & 7 Aug & 8 Aug & 15 Aug & 16 Aug & 20 Aug & 22 Aug \\
\hline $\begin{array}{l}\text { 1. Jordan Park / Arik } \\
\text { Bridge }\end{array}$ & 820 & 400 & & & 1000 & 1200 & 470 \\
\hline $\begin{array}{l}\text { 2. Meshushim pool } \\
\text { a }\end{array}$ & 620 & 300 & & 1100 & 880 & 1110 & 1000 \\
\hline 3. Gilabon stream & 640 & 500 & & & 1440 & 1600 & 3200 \\
\hline 4. Zavitan stream & 60 & & 3600 & 500 & & 310 & 360 \\
\hline $\begin{array}{l}\text { 5. Yehudiya forest } \\
\text { reserve }\end{array}$ & 440 & 600 & & 1170 & & 4560 & 2560 \\
\hline 6. Zaki stream & 2170 & 900 & 1500 & 4400 & & 4000 & 3840 \\
\hline 7. The Majrasa & 520 & 250 & & & 800 & 2480 & 1100 \\
\hline
\end{tabular}

${ }^{\text {aW }}$ ater bodies tested positive for pathogenic Leptospira by realtime PCR.

Serial faecal coliform counts (colony forming units (cfu)/10omL) used as a surrogate marker for water contamination with animal excretions in the seven water sources implicated in acquisition of leptospirosis in Northern Israel. Green, yellow and orange denote counts of $\langle 400,400-1,000$ or $>1,000$, respectively, per regulatory thresholds used for risk assessment and risk management.

were common while rash and conjunctivitis were rare. The majority $(n=31)$ of confirmed cases were hospitalised, 12 had hepatic or renal involvement and one patient developed pneumonia. Three were reported to have been admitted to an intensive-care unit; no deaths were reported. There was one travel-associated case reported in a German tourist who developed severe leptospirosis [3], it is thought that this case was exposed in early June.

The geographic distribution of cases is shown in Figure 2. Exposure data were available for 540 cases (87.2\%); all 36 confirmed and probable cases had exposures to one or more of seven recreational water bodies in the weeks before onset of illness; for the remaining 504 suspected cases, 645 potential exposures were noted, of which $423(65.5 \%)$ involved the implicated water bodies.

\section{Environmental investigation}

Laboratory surveillance for faecal contamination (Figure 3) revealed abnormal faecal coliform counts on repeated measurements from all water bodies, supporting the decision for site closure to the public. Subsequent MST of the initial four water sources identified heavy faecal contamination attributed to wild boar and cattle, with only a trace of human faeces. Positive serological tests by MAT were reactive against a range of serovars as commonly seen in early leptospirosis. The Pomona and Burgas antigens (Serovars Pomona and Balcanica, respectively) were particularly reactive (seven and ten cases, respectively) with titres ranging from 1:200 to 1:1,600. The Pomona serovar, in particular, is naturally adapted to wild boar and there have been recent reports from the Israeli veterinary authorities on the emergence of $L$. Pomona infection in wild boar and cattle in Northern Israel [4]. Faecal contamination of water bodies from wild boar and cattle origin, in combination with clinical infection with the Pomona serovar, support human infection acquired through exposure to animal excretions during recreational activity under favourable conditions for transmission, i.e. drought and relative water stagnation.

\section{Discussion}

The severity of leptospirosis varies greatly, ranging from asymptomatic infection to mild influenza-like illness to a severe life-threatening infection (Weil's disease) [5]. The severity of infection depends on the type of exposure, the human host and the infecting serovar. Human infection commonly involves direct or indirect exposure to infected urine originating from animal reservoirs, this can occur both recreationally or occupationally [6]. While many cases are sporadic, outbreaks of human leptospirosis have been occasionally reported.

Human leptospirosis is uncommon in Israel; data from the $\mathrm{MOH}$ surveillance of notifiable diseases suggest less than 10 confirmed cases have occurred per annum over the last decades [7]. An outbreak of seven cases of leptospirosis acquired during combat training of soldiers was reported in 2002 and was caused by a low pathogenicity serovar (L. Hardjo) commonly found in cattle in Israel [8]. The current outbreak is much larger and subject to ongoing investigation and case surveillance. To date it has involved considerable communication challenges, with respect to the risk of contracting leptospirosis in certain locations, while providing assurance for the safety of continued recreational activities in the region as a whole. Difficulty in obtaining accurate travel history for cases in the weeks following possible exposure was particularly challenging. To overcome challenges during this outbreak, communication strategies involved not only national web-based, electronic and printed media, but also externalisation of visual aids based on geographic information systems (GIS). Since the North of Israel is a popular site for domestic and international tourism, especially during the summer, cases may show up elsewhere in returning travellers. Individuals meeting the case definition may therefore be considered as suspected cases.

In addition, the relevant government agencies have used water originating from other regional water sources to help increase the water flow to the implicated water bodies; thus, reducing stagnation and helping to dilute and wash away faecal contamination. To date, four sites have been targeted for increased water flow, while monitoring of effectiveness continues using serial faecal coliform as well as MST testing. In the absence of validated regulatory tests for environmental contamination with pathogenic Leptospira, the 
criteria for re-opening of water bodies for the public visit are complex. Currently, they rely on a combination of epidemiological data and direct and indirect microbiological tests as part of an ongoing risk assessment. Long-term solutions are currently being considered to prevent further water contamination. These include improved control of animal leptospirosis in ruminants, through employing repeated testing, antimicrobial treatment and vaccination with polyvalent vaccines containing the implicated serovar. In addition, solutions for prevention of further contamination by providing designated water sources (basins) and limiting natural water access of free-ranging animals are currently being considered and involve a cross-sectoral effort of multiple government offices.

\section{Acknowledgements}

The authors would like to acknowledge healthcare personnel at hospitals and community clinics, particularly infectious disease specialists, personnel at the $\mathrm{MOH}$ district health offices and departments, scientists at clinical, public health and reference laboratories, and staff members working within all stakeholder organisations, for their contribution to patient treatment and incident management.

\section{Conflict of interest}

None declared.

\section{Authors' contributions}

Jacob Moran-Gilad, Eric Haas, Yuval Dadon and Ehud Kaliner wrote the first draft of the manuscript; Emilia Anis, Roee Singer and Eva Avramovich contributed to epidemiological data analysis; Sharon Amit and Ian Miskin contributed to formulation of guidance and risk assessment; Yafit AtiyaNasagi, Oded Sued, Roni King, Efrat Gino and Ruth Yishai contributed to clinical, veterinary and environmental sample collection and laboratory results; Michal Cohen-Dar, Rivka Sheffer and Itamar Grotto contributed to risk assessment and incident management; All authors revised and approved the final version of the manuscript.

\section{References}

1. Centers for Disease Control and Prevention (CDC). Leptospirosis 2013 case definition. Atlanta: CDC. [Accessed on 14 Sep 2018]. Available from: https://wwwn.cdc.gov/nndss conditions/leptospirosis/case-definition/2013/

2. Stoeckel DM, Harwood VJ. Performance, design, and analysis in microbial source tracking studies. Appl Environ Microbiol. 2007;73(8):2405-15. https://doi.org/10.1128/AEM.02473-06 PMID: 17308193

3. ProMED-mail. Leptospirosis - Israel (03): (HZ) streams, German tourist, early patient. Archive Number 20180817.5970939. 16 August 2018. Available from: https://www.promedmail.org/ post/20180817.5970939

4. ProMED-mail. Leptospirosis - Israel (o4): (HZ) recreation, streams, animal reservoir. Archive Number 20180818.5973544. 18 August2018. Available from:https://www.promedmail.org

5. Bharti AR, Nally JE, Ricaldi JN, Matthias MA, Diaz MM, Lovett MA, et al. Peru-United States Leptospirosis Consortium. Leptospirosis: a zoonotic disease of global importance. Lancet Infect Dis. 2003;3(12):757-71. https://doi.org/10.1016/S14733099(03)00830-2 PMID: 14652202

6. Levett PN. Leptospirosis. Clin Microbiol Rev. 2001;14(2):296326. https://doi.org/10.1128/CMR.14.2.296-326.2001 PMID: 11292640
7. State of Israel Ministry of Health $(\mathrm{MOH})$. Notifiable Infectious Diseases in Israel: 60 years of surveillance 1951-2010. Israeli. Israel: MOH. [Accessed 14 Sept 2018] Available at: https:// www.health.gov.il/PublicationsFiles/Disease1951_2010.pdf

8. Hadad E, Pirogovsky A, Bartal C, Gilad J, Barnea A, Yitzhaki $\mathrm{S}$, et al. An outbreak of leptospirosis among Israeli troops near the Jordan River. Am J Trop Med Hyg. 2006;74(1):127-31. https://doi.org/10.4269/ajtmh.2006.74.127 PMID: 16407357

\section{License and copyright}

This is an open-access article distributed under the terms of the Creative Commons Attribution (CC BY 4.0) Licence. You may share and adapt the material, but must give appropriate credit to the source, provide a link to the licence, and indicate if changes were made.

This article is copyright of the authors or their affiliated institutions, 2018. 